\title{
SAÚDE NA ESCOLA - APRENDENDO MAIS SOBRE O DIABETES
}

\author{
AUTOR: BRUNA MARTINS GRASSI SEDLMAIER \\ CO-AUTOR/ORIENTADOR: DENISE MACHADO MOURAO
}

\begin{abstract}
Resumo: O presente estudo objetivou realizar levantamento situacional quanto a incidência de diabetes mellitus em alunos de escolas municipais de Teixeira de Freitas/BA, verificar o conhecimento de alunos e profissionais escolares sobre diabetes, e promover educação em diabetes. Trata-se de uma pesquisa ação de caráter qualitativo, com delineamento descritivo. O levantamento situacional se deu primeiramente pela identificação do quantitativo de escolas da rede pública municipal junto à Secretaria de Educação, e posteriormente por contato telefônico com as diretoras ou coordenadoras das escolas. Para verificar o conhecimento dos participantes foram realizadas entrevistas. As ações envolveram encenações teatrais, dinâmicas e momentos de conversa. Após as ações, foi distribuído o material impresso do Pacote Educacional KiDS, no intuito de fixar o conteúdo. As entrevistas foram realizadas em duas escolas, totalizando 307 alunos e 47 funcionários entrevistados. Na pergunta "o colega com diabetes pode dançar, pular e correr?", apenas 35\% dos alunos responderam 'sim'. Na pergunta "o aluno com diabetes pode ficar irritado ou nervoso sem motivo", apenas $45 \%$ dos funcionários responderam 'sim'. Do total de 29 escolas, 15 informaram que não havia aluno com diabetes, 4 não sabiam e em 10 havia pelo menos 1. Destas, 7 afirmaram ter 1 aluno, 2 tinham 2 alunos, e 1 tinha 5 alunos. As ações educativas foram realizadas em uma escola, e envolveram aproximadamente 234 pessoas, entre alunos e funcionários. $O$ desconhecimento sobre a existência de alunos com diabetes em algumas escolas, percebido no levantamento situacional, demonstra fragilidades na assistência à esses estudantes. Embora em aspectos gerais o conhecimento de estudantes e funcionários das escolas estudadas sobre diabetes tenha demonstrado fragilidades, as ações educativas para esse público representam uma forma de promover conhecimentos sobre o tema, propiciando um ambiente escolar mais seguro para os alunos com diabetes. Logo, chamar a atenção para essa condição pode favorecer uma melhor proteção dos alunos com diabetes na escola.
\end{abstract}

Palavras-chave: Diabetes Mellitus, Educação em Saúde, Serviços de Saúde Escolar. 